\title{
Water Use Efficiency of Cassava Plants under Competition Conditions ${ }^{1}$
}

\author{
Eficiência do Uso da Água de Plantas de Mandioca em Condições de Competição
}

\author{
ASPIAZÚ, I. ${ }^{2}$, SEDIYAMA, T. ${ }^{3}$, RIBEIRO JR., J.I. ${ }^{4}$, SILVA, A.A. ${ }^{3}$, CONCENCO, G. ${ }^{5}$, FERREIRA, E.A. ${ }^{6}$, \\ GALON, L. ${ }^{7}$, SILVA, A.F. ${ }^{8}$, BORGES, E.T. ${ }^{9}$ e ARAUJO, W.F. ${ }^{10}$
}

\begin{abstract}
The objective of this work was to evaluate characteristics associated with the photosynthetic activity of cassava plants in competition with weeds or not. The trial was performed on open environment conditions, with experimental units consisting of fiber glass vases with $150 \mathrm{dm}^{3}$ filled with Red Yellow Latosol, previously fertilized. Treatments consisted in the cultivation of cassava plants isolated and associated to three weed species (Bidens pilosa, Commelina benghalensis and Brachiaria plantaginea). After cassava shooting, 15 days after planting, a removal of the weeds excess was performed, sown at the time of cassava planting, leaving six plants $\mathrm{m}^{-2}$ of $B$. pilosa and four plants $\mathrm{m}^{-2}$ of $C$. benghalensis and $B$. plantaginea. At 60 days after emergence (DAE), stomatal conductance (Gs), vapor pressure in the substomatal cavity $\left(\mathrm{E}_{\text {an }}\right)$, temperature gradient between leaf and air $(\Delta \mathrm{T})$, transpiration rate $(\mathrm{E})$ and water use efficiency (WUE) were evaluated. B. pilosa showed greater capacity to affect growth of cassava plants. B. plantaginea is very efficient in using water, especially by presenting $\mathrm{C}_{4}$ metabolism, and remains competitive with cassava even under temporarily low water status. C. benghalensis, in turn, is not a good competitor for light and apparently is not the primary cause of water depletion in the soil. The effects of weeds, in this case, were more associated with the competition. However, they were found between moderate to low. This implies that the competition established at experimental level was low.
\end{abstract}

Keywords: Bidens pilosa, Commelina benghalensis, Brachiaria plantaginea, interference.

\begin{abstract}
RESUMO - Objetivou-se com este trabalho avaliar características associadas à eficiência de uso da água de plantas de mandioca sob competição ou não com plantas daninhas. O experimento foi realizado em condições de ambiente aberto, sendo as unidades experimentais compostas por vasos de fibra de vidro de $150 \mathrm{dm}^{3}$ preenchidos com Latossolo Vermelho Amarelo, previamente adubado. Os tratamentos consistiram no cultivo de plantas de mandioca isoladas e associadas a três espécies daninhas (Bidens pilosa, Commelina benghalensis e Brachiaria plantaginea). Após início da brotação das manivas, 15 dias após o plantio, fez-se o desbaste das plantas daninhas, semeadas no momento do plantio das manivas, deixando-se oito plantas de B. pilosa, quatro de C. benghalensis e quatro de B. plantaginea. Aos 60 dias após a emergência (DAE), foram avaliados a condutância estomática de vapores de água (Gs), pressão de vapor na câmara subestomática $\left(E_{a r}\right)$, gradiente entre temperatura da folha e do ar $(\Delta T)$, taxa de transpiração $(E)$ e a eficiência do uso da água (EUA). A espécie B. pilosa demonstrou maior capacidade de afetar o crescimento das plantas de mandioca. B. plantaginea é muito eficiente em utilizar a água, principalmente por apresentar metabolismo $C_{4}$, e se mantém competitiva com a mandioca mesmo sob baixo status hídrico temporário. C. benghalensis, por sua vez, não é boa competidora por luz e aparentemente não é causadora primária do esgotamento da água no solo. Os efeitos, nesse caso, das plantas daninhas, foram mais associados à competição. No entanto, eles foram considerados entre moderados a baixos. Isso implica que a competição estabelecida a nível experimental foi baixa.
\end{abstract}

Palavras-chave: Bidens pilosa, Commelina benghalensis, Brachiaria plantaginea, interferência

Recebido para publicação em 12.10.2009 e na forma revisada em 12.11.2010

2 Engo-Agr ${ }^{\circ}$., D.Sc., Professor, Universidade Estadual de Montes Claros - UNIMONTES, Janaúba-MG, <aspiazu@gmail.com>;

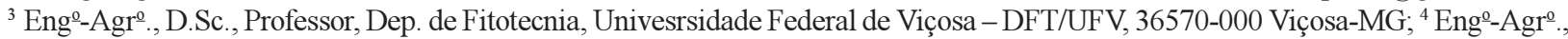
D.Sc., Prof., Dep. de Estatística, DPE/UFV; ${ }^{5}$ Eng-o-Agr $^{0}$., D.Sc., Valmont Industries, Inc. USA. Valmont Industries - Irrigation Division, 7002 North 288th Street, P.O. Box 358, Valley, NE 68064 USA; ${ }^{6}$ Eng$^{0}-$ Agr $^{\circ}{ }^{\circ}$., D.Sc., Bolsista PNPD, Universidade Federal dos Vales do Jequitinhonha e Mucuri - UFVJM, Diamantina-MG; ${ }^{7}$ Eng $^{\circ}$-Agr ${ }^{0}$., D. Sc., Professor, Universidade Federal do Pampa - UNIPAMPA, Itaqui-RS; ${ }^{8}$ Engo-Agro $^{-}$, D.Sc.; ${ }^{9}$ Estudante de Graduação do Curso de Agronomia, UFV, bolsista de iniciação científica; ${ }^{10}$ Eng $^{-}-$Agr $^{\circ}$., D. Sc., Prof., Universidade Federal de Roraima - UFRR, Boa Vista-RR.

Planta Daninha, Viçosa-MG, v. 28, n. 4, p. 699-703, 2010 


\section{INTRODUCTION}

Several factors have contributed to the low productivity of cassava at a national level, being the inadequate management of weeds one of the most important. Normally, cassava producers believe that this crop is rustic and there is no need to worry too much about weed control (Albuquerque, 2008). However, the competition between weeds and cassava can affect its production in quantitative and qualitative ways (Carvalho, 2006). This competition alters the utilization efficiency of environmental resources such as water, light, nutrients and space among species that occupy the same ecological niche (Sinclair et al., 1975, Melo et al., 2006).

Although three quarters of the planet's surface are covered by water, only about $0.31 \%$, are actually available. Therefore, water is a resource not as abundant as we think (Esteves, 1988) and is poorly distributed, making it imperative that cultivation system fosters efficiency in its use. Water use efficiency is defined by the relationship between grams of water transpired by a crop per gram of dry matter produced. Therefore, crops that use water more efficiently produce more dry matter per gram of water transpired, so the efficient use of water is directly correlated to time of opening and stomatal conductance or resistance. As the plant absorbs $\mathrm{CO}_{2}$ for photosynthesis, water is lost by transpiration, with variable intensity depending on the potential gradient between leaf surface and the atmosphere, following a stream of water potentials (Pereira-Netto et al., 2002).

When plants are subjected to strong competition in the plant community, the physiological characteristics of growth and development are usually changed, which results in differences in the use of environmental resources, especially in the use of water, which directly affects the availability of $\mathrm{CO}_{2}$ in leaf mesophyll and the leaf temperature, hence the photosynthetic efficiency (Procópio, 2004).

The objective of this work was to evaluate characteristics associated with the efficiency of water use in the cassava crop subjected to competition with Bidens pilosa, Commelina benghalensis and Brachiaria plantaginea.

\section{MATERIAL AND METHODS}

The experiment was conducted in the Experimental Field Professor Diogo Alves de Mello, a part of the Phytotechny Department, at Universidade Federal de Viçosa (UFV) and the experimental units consisted of fiberglass vases, with a capacity of $150 \mathrm{dm}^{3}$, filled with Red Yellow Latosol previously fertilized according to fertilization recommendations by Cantarutti et al. (2007). All vases were perforated at the base and received a $5 \mathrm{~cm}$ layer of crushed stone before being filled with the soil, aiming to drain excess of water from rain or irrigation. Throughout the period of duration of the experiment soil, moisture was maintained at about $2 / 3$ of field capacity by periodical irrigation according to needs.

For the installation of the experiment, one stem cutting of cassava with $15 \mathrm{~cm}$ in length was planted in each experimental unit. At the same time as the specified treatment, the weeds Bidens pilosa (three plants per $\mathrm{m}^{-2}$ ) or Brachiaria plantaginea (six plants per $\mathrm{m}^{-2}$ ), were sown in each experimental plot, being the Commelina benghalensis transplanted by seedlings (three plants per $\mathrm{m}^{-2}$ ). The experimental design was randomized blocks with three replications, in a $3 \times 8$ factorial. Plants from the soil seed bank were removed weekly by manual harvesting. Weed densities on the experimental units were defined consulting experts in this area.

At 60 days after crop emergence (DCE), data were collected with an LCA-4 infra-red gas analyzer (ADC Bioscientific, Herts, UK). These tests were performed in the first fully expanded leaf, from the apex, of cassava plants in the morning, between 8 and 10 AM. Each block was examined in one morning, in order to maintain the environmental conditions as homogeneous as possible. The following evaluations were made: stomatal conductance $\left(\mathrm{Gs}=\mathrm{mol} \mathrm{m} \mathrm{m}^{-1} \mathbf{s}^{-1}\right)$, vapor pressure in the substomatal cavity $\left(\mathrm{E}_{\mathrm{an}}=\mathrm{mbar}\right)$, temperature gradient between the leaf and air $\left(\Delta \mathrm{T}={ }^{\circ} \mathrm{C}\right)$, transpiration rate $\left(\mathrm{E}=\mathrm{mol} \mathrm{H}_{2} \mathrm{O} \mathrm{m}^{-2} \mathrm{~s}^{-1}\right)$, and water use efficiency [WUE $=\mathrm{mol} \mathrm{CO}_{2} \mathrm{~mol}$ $\left(\mathrm{H}_{2} \mathrm{O}\right)^{-1}$, calculated using the values of the 
amount of $\mathrm{CO}_{2}$ fixed by photosynthesis and amount of water transpired.

Data were submitted to variance analysis by F-test, and in case of significance, the means were compared in pairs by test of least significant difference (LSD). All tests were performed at $5 \%$ probability significance level, using the SAEG statistical software. Among the variables studied, the Pearson correlations were estimated and tested by t-test.

\section{RESULTS AND DISCUSSION}

The stomatal conductance (Gs) of cassava plants in coexistence with $B$. pilosa was inferior only to the treatment where cassava was grown alone (Table 1). B. pilosa is widely known for having high capacity for extraction of soil water and being able to maintain growth under water potentials in which most plants have reached the permanent wilting point (Procópio et al., 2004).

The leaf conductance is composed by Gs and, in small part, by the conductance of the cuticular epidermis. When the stomata are open, the Gs is controlled almost entirely by the guard cells, and is directly correlated to transpiration (Table 2). Thus, Gs is proportional to the number, size and diameter of the opening of stomata, characteristics that depend on other environmental and endogenous factors (Brodribb \& Holbrook, 2003). The control of stomatal opening and closing depends on a number of factors such as solar radiation, $\mathrm{CO}_{2}$ levels in the mesophyll, relative humidity (air vapor pressure deficit), water potential, and others of lesser magnitude such as wind, growth substances and endogenous rhythms of each species.

Vapor pressure in the substomatal cavity of the cassava leaves $\left(\mathrm{E}_{\text {an }}\right)$ was not changed in function of the competition between the cassava plants and the species $B$. pilosa, $C$. benghalensis and B. plantaginea (Table 1 ). The $E_{\text {an }}$ is directly related to the plant water status and to the dynamic flow of water vapor. Even in a leaf transpiring quickly, relative humidity in the cavity may exceed 95\%, and the resulting water potential can be close to zero, increasing exchanges with the environment, which has a very negative water potential. Under these conditions, the vapor pressure would be the vapor pressure of saturation at the leaf temperature. Thus, the $\mathrm{E}_{\mathrm{an}}$ is controlled by humidity level and leaf temperature, and acts on the stomatal conductance of water vapor (Gs) and transpiration (E). In Table 2, a high correlation between $\mathrm{E}$ and $\mathrm{E}_{\mathrm{an}}$ can be observed, although the latter was not modified in function of the species with which cassava competed. As $\mathrm{E}_{\text {an }}$ was not changed depending on the weed species with which the crop competed, the changes in Gs can attributed to factors not related to cassava plants, such as availability of soil water or wind speed, factors that can be changed by the presence of weeds.

Increases in metabolism may be indirectly measured as a function of leaf temperature. Typically, the temperature difference between the leaf and the air around it is only one or two degrees, but in extreme cases can exceed

Table 1 - Physiological components of cassava plants 60 days after emergence, in function of the competition with $B$. pilosa, C. benghalensis or B. plantaginea

\begin{tabular}{|c|c|c|c|c|c|}
\hline Treatment & $\begin{array}{c}\mathrm{E}^{4 /} \\
\left(\mathrm{mol} \mathrm{H} \mathrm{O}_{2} \mathrm{O}^{-2} \mathrm{~s}^{-1}\right) \\
\end{array}$ & $\begin{array}{c}\mathrm{Gs}^{5 /} \\
\left(\mathrm{mol} \mathrm{m}^{-1} \mathrm{~s}^{-1}\right) \\
\end{array}$ & $\begin{array}{l}\mathrm{T}_{\text {leaf }}{ }^{6 /} \\
\left({ }^{\circ} \mathrm{C}\right) \\
\end{array}$ & $\begin{array}{c}\mathrm{E}_{\mathrm{an}}{ }^{7 /} \\
(\mathrm{mBar})\end{array}$ & $\begin{array}{c}\mathrm{EUA}^{\underline{8} /} \\
\left(\mathrm{mol} \mathrm{CO} \mathrm{mol} \mathrm{H}_{2} \mathrm{O}^{-1}\right)\end{array}$ \\
\hline Weed free cassava control & $3,57 a^{*}$ & $0,13 \mathrm{a}$ & $32,1 \mathrm{~b}$ & $22,40 \mathrm{a}$ & $1,81 \mathrm{~b}$ \\
\hline Cassava $\times$ B. pilosa $a^{1 /}$ & $2,31 \mathrm{c}$ & $0,07 \mathrm{~b}$ & $33,6 \mathrm{ab}$ & $21,03 \mathrm{a}$ & $2,26 \mathrm{a}$ \\
\hline Cassava x C. benghalensis ${ }^{2 /}$ & $3,69 \mathrm{a}$ & $0,11 \mathrm{ab}$ & $35,1 \mathrm{a}$ & $24,57 \mathrm{a}$ & $1,98 \mathrm{ab}$ \\
\hline Cassava $\times$ B. plantaginea $a^{3 /}$ & $3,15 \mathrm{~b}$ & $0,12 \mathrm{ab}$ & $33,6 \mathrm{ab}$ & $23,47 \mathrm{a}$ & $1,90 \mathrm{ab}$ \\
\hline $\mathrm{CV}(\%)$ & 19,7 & 24,40 & 3,60 & 6,6 & 9,8 \\
\hline
\end{tabular}

1/ Cassava competing with eight plants of Bidens pilosa; ${ }^{2 /}$ Cassava competing with four plants of Commelina benghalensis; ${ }^{3 /}$ Cassava competing with four plants of Brachiaria plantaginea; ${ }^{4 /}$ Transpiration rate; ${ }^{5 /}$ Stomatal conductance of water vapor. ${ }^{6 /}$ Temperature gradient between leaf and air; ${ }^{7 /}$ Vapor pressure in the substomatal cavity of cassava leaves; $\stackrel{8}{ }$ Water use efficiency. ${ }^{*}$ Means followed by the same letter, in columns, do not differ by LSD test at $5 \%$ probability. 
Table 2 - Pearson correlation matrix between the physiological variables of cassava plants, evaluated 60 days after emergence

\begin{tabular}{|l|c|c|c|c|}
\hline & $\begin{array}{c}\mathrm{E}^{1 /} \\
\left(\mathrm{mol} \mathrm{H}_{2} \mathrm{O} \mathrm{m}^{-2} \mathrm{~s}^{-1}\right)\end{array}$ & $\begin{array}{c}\mathrm{Gs}^{2 /} \\
\left(\mathrm{mol} \mathrm{m}^{-1} \mathrm{~s}^{-1}\right)\end{array}$ & $\begin{array}{c}\mathrm{T}_{\text {leaf }}^{3 /} \\
(\Delta \mathrm{T})\end{array}$ & $\begin{array}{c}\mathrm{E}_{\mathrm{an}}^{4 /} \\
(\mathrm{mBar})\end{array}$ \\
\hline $\mathrm{Gs}\left(\mathrm{mol} \mathrm{m}^{-1} \mathrm{~s}^{-1}\right)$ & $0,72^{*}$ & & & \\
\hline $\mathrm{T}_{\text {leaf }}\left({ }^{\circ} \mathrm{C}\right)$ & 0,22 & $-0,36$ & & \\
\hline $\mathrm{E}_{\text {an }}(\mathrm{mBar})$ & $0,87^{*}$ & 0,49 & 0,52 & $-0,09$ \\
\hline EUA $\left(\mathrm{mol} \mathrm{CO}_{2} \mathrm{~mol} \mathrm{H}_{2} \mathrm{O}^{-1}\right)^{5 /}$ & $-0,26$ & $-0,30$ & 0,23 & \\
\hline
\end{tabular}

1/ Transpiration rate; ${ }^{2 /}$ Stomatal conductance of water vapor. ${ }^{3 /}$ Temperature gradient between leaf and air; ${ }^{4 /}$ Vapor pressure in the substomatal cavity of cassava leaves; $\stackrel{5}{5}$ Water use efficiency. ${ }^{*}$ Significant $(\mathrm{P}<0,05)$.

$5{ }^{\circ} \mathrm{C}$ (Drake \& Salisbury, 1972; Atkin et al., 2000). The leaf temperature $\left(\mathrm{T}_{\text {leaf }}\right)$ was lower in the control free of competition compared to the plant that competed with $C$. benghalensis (Table 1). Cassava plants that were in competition with B. pilosa or B. plantaginea stood at an intermediate level of leaf temperature, not differing from the control or the plant competing with $C$. benghalensis, which indicates a moderate degree of interference. When compared to the control, the temperature in cassava leaves was 3.0, 1.5 and $1.5^{\circ} \mathrm{C}$ higher than that observed in control leaves, when competing with $C$. benghalensis, $B$. pilosa and B. plantaginea, respectively.

When considering that the competitive strategy of $B$. pilosa is quick depletion of soil water, reaching levels not supported by most other plants, it can be stated that C. benghalensis does not have the same ability, because the leaf temperature of cassava plants was higher when competing with it. This indicates that, in this situation, the cassava metabolism was more active than when it was competing with other weeds. Moreover, the small size of $C$. benghalensis may have caused low competition for light with the crop, thus being an advantageous environment for it (Table 1).

The transpiration rate (E) was dependent $(\mathrm{P}<0.05)$ on the weed species with which the cassava plant competed, being superior for free control weeds and for the cassava plant which competed with $C$. benghalensis. This supports the considered hypothesis that $C$. benghalensis does not show a good competitive ability for light, because the crop had higher leaf temperature and higher transpiration intensity when competing with this species, which indicates high metabolic rate and accelerated growth due to low competition (Table 1). B. plantaginea, on the other hand, caused a moderate reduction $(\mathrm{P}<0.05)$ in the transpiration intensity of cassava plants, while $B$. pilosa reduction $(\mathrm{P}<0.05)$ was severe. As previously mentioned, the competitive strategy of $B$. pilos $a$ is the extraction of soil water to levels supported by it, but not by the plants with which it competes. Thus, it seems that there could be low water in the soil, resulting in lack of water for the cassava plants that would not cause negative effect to the $B$. pilosa mainly in function of the reduced transpiration intensity. The strategy of $B$. plantaginea is probably different from the $B$. pilosa species, because the decrease in the soil water level may have been smaller, and probably that is why the cassava plant managed to keep more appropriate transpiration levels. The effects, in this case, were more associated with the competition. However, they were considered moderate to low. This implies that the competition set in this experiment was low.

The water use efficiency (WUE) is defined by the relationship between grams of water transpired by a crop per gram of dry matter produced. It is therefore highly influenced by the type of carbon metabolism of the species and other morphophysiological features, such as stomatal opening and density, leaf surface coating (presence of trichomes and epicuticular wax) and stomata positioning related to the leaf surface (flat or in cavities). The WUE is also influenced by environmental factors such as leaf temperature, wind speed and relative humidity. When under mild 
temperature conditions, cassava plants are usually very efficient in using water, that is, they lose less water than many other species, for the fixation of the same amount of $\mathrm{CO}_{2}$ (E1-Sharkawy, 2003). This experiment was evaluated under higher temperatures, around $30{ }^{\circ} \mathrm{C}$, which resulted in values lower than the normally reported WUE for cassava plants (E1-Sharkawy \& Cock, 1984). However, the comparison between treatments clarifies that, in the absence of competition, the cassava plants were more efficient in the use of water, especially when competing with $B$. pilosa; this happens directly in function of the lower transpiration observed in this situation, due to a lack of water created against the culture (Table 1).

The B. pilosa species showed greater capacity to affect the growth of cassava plants, due mainly to their ability to deplete soil water and continue to develop under low water potential. $B$. plantaginea is very efficient in using water, especially by having a $\mathrm{C}_{4}$ metabolism, and remains competitive with cassava even under temporary low water status conditions. Furthermore, it is efficient in the competition for light due to high dry matter production, which can easily shade younger cassava plants. C. benghalensis, in turn, is not a good competitor for light and apparently is not the primary cause of water depletion in the soil, which characterizes it as a species of low competitive ability with cassava.

\section{ACKNOWLEDGEMENTS}

To the Research Foundation of the State of Minas Gerais (FAPEMIG) for financial support for publishing this paper.

\section{LITERATURE CITED}

ALBUQUERQUE, J. A. A. et al. Interferência de plantas daninhas sobre a produtividade da mandioca (Manihot esculenta). Planta Daninha, v. 26, n. 2, p. 279-289, 2008.

ATKIN, O. K. et al. Leaf respiration of snow gum in the light and dark. interactions between temperature and irradiance. Plant Physiol., v. 122, n. 3, p. 915-923, 2000.
BRODRIBB, T. J.; HOLBROOK, N. M. Stomatal closure during leaf dehydration, correlation with other leaf physiological traits. Plant Physiol., v. 132, n. 4, p. $2166-2173,2003$

CANTARUTTI, R. B. et al. Avaliação da fertilidade do solo e recomendação de fertilizantes. In: NOVAIS R. F. et al. Fertilidade do solo. Visconde do Rio Branco: Suprema, 2007. v. 1. p. $769-850$.

CARVALHO, J. E. B.; PERESSIN, V. A.; ARAÚJO, A. M. A Manejo e controle de plantas daninhas. In: SOUZA, L. S. et al. (Eds.). Aspectos socioeconômicos e agronômicos da mandioca Cruz das Almas: Embrapa Mandioca e Fruticultura Tropical, 2006. 817 p.

DRAKE, B. G.; SALISBURY, F. B. Aftereffects of low and high temperature pretreatment on leaf resistance, transpiration, and leaf temperature in Xanthium. Plant Physiol., v. 50, n. 5, p. 572-575, 1972.

EL-SHARKAWY, M. A. \& COCK, J. H. Water use efficiency of cassava. I. Effects of air humidity and water stress on stomatal conductance and gas exchange. Crop Sci., v. 24, p. 497-502, 1984.

EL-SHARKAWY, M. A. Cassava biology and physiology. Plant Molec. Biol., v. 53, n. 5, p. 621-641, 2003.

ESTEVES, F. A. Fundamentos de limnologia. São Paulo: Intersciência/FINEP, 1988. 575 p.

MELO, P. T. B. S. et al. Comportamento de populações de arroz irrigado em função das proporções de plantas originadas de sementes de alta e baixa qualidade fisiológica. R. Bras.

Agroci., v. 12, n. 1, p. 37-43, 2006.

PEREIRA-NETTO, A. B. Crescimento e desenvolvimento. In: WACHOWICZ, C. M.; CARVALHO, R. I. N. (Eds.). Fisiologia vegetal - produção e pós-colheita. Curitiba: Champagnat, 2002. p. 17-42.

PROCÓPIO, S. O. et al. Ponto de murcha permanente de soja, feijão e plantas daninhas. Planta Daninha, v. 22, n. 1, p. $35-41,2004$.

ROCHA, D. C. et al. Efeito de herbicidas sobre quatro espécies de trapoeraba. Planta Daninha, v. 25, n. 2, p. 359-364, 2007.

SINCLAIR, T. R. et al. Water use efficiency of field-grown maize during moisture stress. Plant Physiol., v. 56, p. $245-249,1975$. 